\title{
Alstroemeria yellow spot virus (AYSV): a new orthotospovirus species within a growing Eurasian clade
}

\author{
A. Hassani-Mehraban ${ }^{1}$ - A. M. Dullemans ${ }^{1} \cdot$ J. Th. J. Verhoeven ${ }^{2} \cdot$ J. W. Roenhorst ${ }^{2}$ - D. Peters ${ }^{1} \cdot$ R. A. A. van der Vlugt ${ }^{1}$. \\ R. Kormelink ${ }^{1}$ (i)
}

Received: 15 May 2018 / Accepted: 28 August 2018 / Published online: 4 October 2018

(c) The Author(s) 2018

\begin{abstract}
An orthotospovirus distinct from all other orthotospoviruses was isolated from naturally infected alstroemeria plants. Disease symptoms caused by this virus mainly consisted of yellow spots on the leaves based on which the name alstroemeria yellow spot virus (AYSV) was coined. A host range analysis was performed and a polyclonal antiserum was produced against purified AYSV ribonucleoproteins which only reacted with the homologous antigen and not with any other (established or tentative) orthotospovirus from a selection of American and Asian species. Upon thrips transmission assays the virus was successfully transmitted by a population of Thrips tabaci. The entire nucleotide sequence of the M and S RNA segments was elucidated by a conventional cloning and sequencing strategy, and contained 4797 respectively 2734 nucleotides (nt). Simultaneously, a next generation sequencing (NGS) approach (RNAseq) was employed and generated contigs covering the entire viral tripartite RNA genome. In addition to the M and S RNA nucleotide sequences, the L RNA (8865 nt) was obtained. The nucleocapsid (N) gene encoded by the S RNA of this virus consisted of 819 nucleotides with a deduced N protein of 272 amino acids and by comparative sequence alignments to other established orthotospovirus species showed highest homology (69.5\% identity) to the $\mathrm{N}$ protein of polygonum ringspot virus. The data altogether support the proposal of AYSV as a new orthotospovirus species within a growing clade of orthotospoviruses that seem to share the Middle East basin as a region of origin.
\end{abstract}

\section{Introduction}

Members of the Tospoviridae continuously cause significant losses in both mono- and dicot crops worldwide [1, 2]. Although exact numbers indicating the economic impact of orthotospoviruses are not available, annual yield losses

Handling Editor: F. Murilo Zerbini.

A. Hassani-Mehraban and A. M. Dullemans equally contributed.

Electronic supplementary material The online version of this article (https://doi.org/10.1007/s00705-018-4027-z) contains supplementary material, which is available to authorized users.

R. Kormelink

Richard.kormelink@wur.nl

1 Wageningen University and Research, Droevendaalsesteeg 1, 6708 PB Wageningen, The Netherlands

2 The National Plant Protection Organisation (NPPO) of the Netherlands, P.O. Box 9102, 6700 HC Wageningen, The Netherlands have been estimated to exceed at least 1 billion US $\$$ for the type species Tomato spotted wilt virus (TSWV) only [3]. Due to this TSWV ranks high among plant viruses of economic importance worldwide [1, 4-6]. Orthotospoviruses are widespread and transmitted by at least 14 different thrips species $[2,7]$ in a circulative and propagative manner. Virus particles are membrane-bound with a quasi-spherical morphology of about $80-120 \mathrm{~nm}$ in diameter and contain a tripartite ssRNA genome of negative and ambisense polarity [6]. The L RNA is of entire negative polarity and codes for only one gene in the viral complementary (vc) sense, the RNA-dependent RNA polymerase (RdRp; L protein) required for viral replication. The M and S RNA both have an ambisense gene arrangement and contain two ORFs separated by a non-coding intergenic region (IGR). The $\mathrm{M}$ RNA encodes a non-structural $\left(\mathrm{NS}_{\mathrm{M}}\right)$ protein, in the viral (v) sense, that is involved in cell-to-cell movement and a glycoprotein precursor $\left(\mathrm{G}_{\mathrm{N}}-\mathrm{G}_{\mathrm{C}}\right)$ in the vc-sense required for (receptor-mediated) entry into the midgut-epithelium of thrips and vector-specificity [8-13]. The S RNA similarly encodes the non-structural protein (NSs) in the v-sense that 
acts as suppressor of RNA silencing and supports efficient virus transmission by the vector, and the major structural nucleocapsid protein $(\mathrm{N})$ in vc-sense [14-18]. Although host range, vector specificity and serology of the $\mathrm{N}$ protein are often used to identify and/or characterize orthotospoviruses, they only become assigned as a new species if their $\mathrm{N}$ protein exhibits less than $90 \%$ sequence homology to any of the established orthotospovirus species [2, 19, 20].

Ever since TSWV re-emerged in the 1980's and started its world wide spread by the introduction and spread of Frankliniella occidentalis, new viral species have been discovered. This has led to the identification of a current total of 29 orthotospovirus species of which 11 are officially recognized by the ICTV while the remaining, listed as tentative species [2, 20-26]. During the past two decades many viruses have been observed and identified in ornamental crops of which some cause significant economical losses [27].

Currently, alstroemeria is one of the most important and successful cut flowers and its global production is still increasing [28, 29]. However, viral infections place a large constraint on the production levels and limit global trading [30-32]. To date 18 viruses have been reported from alstroemeria plants (Table S1) [29, 32-42] and among those are isolates from five different orthotospovirus species i.e., TSWV, impatiens necrotic spot virus (INSV), iris yellow spot virus (IYSV) [32], tomato yellow ring virus (TYRV) [35] and alstroemeria necrotic streak virus (ANSV) [34]. From these, TSWV has the largest (natural and experimental) host range, exceeding more than 1350 species. INSV infects at least 300 host species, and mainly ornamentals [7], while IYSV and TYRV have a smaller host range and are frequently found in onion, leek and a few ornamentals $[12,35,43,44]$. ANSV has been isolated most recently from alstroemeria in Colombia and, together with TSWV and INSV, clusters within the clade of American/New-World orthotospoviruses [2].

In 2000 an alstroemeria plant showing only chlorotic and yellow spots on the leaves (Figure 1), and reminiscent of a TSWV infection, was received by the Netherlands Inspection Service for Horticulture. Preliminary serological tests with available antisera to a wide range of different orthotospoviruses were negative and indicated the possible emergence of a new orthotospovirus species. Here data is presented on the biological, serological and molecular characterization of this Als-2000 virus isolate to support the proposal of a new tentative orthotospovirus species for which the name alstroemeria yellow spot virus (acronym AYSV) is proposed. The nucleotide sequence of the entire genome was elucidated using a simultaneous conventional and NGS cloning/ sequencing approach.
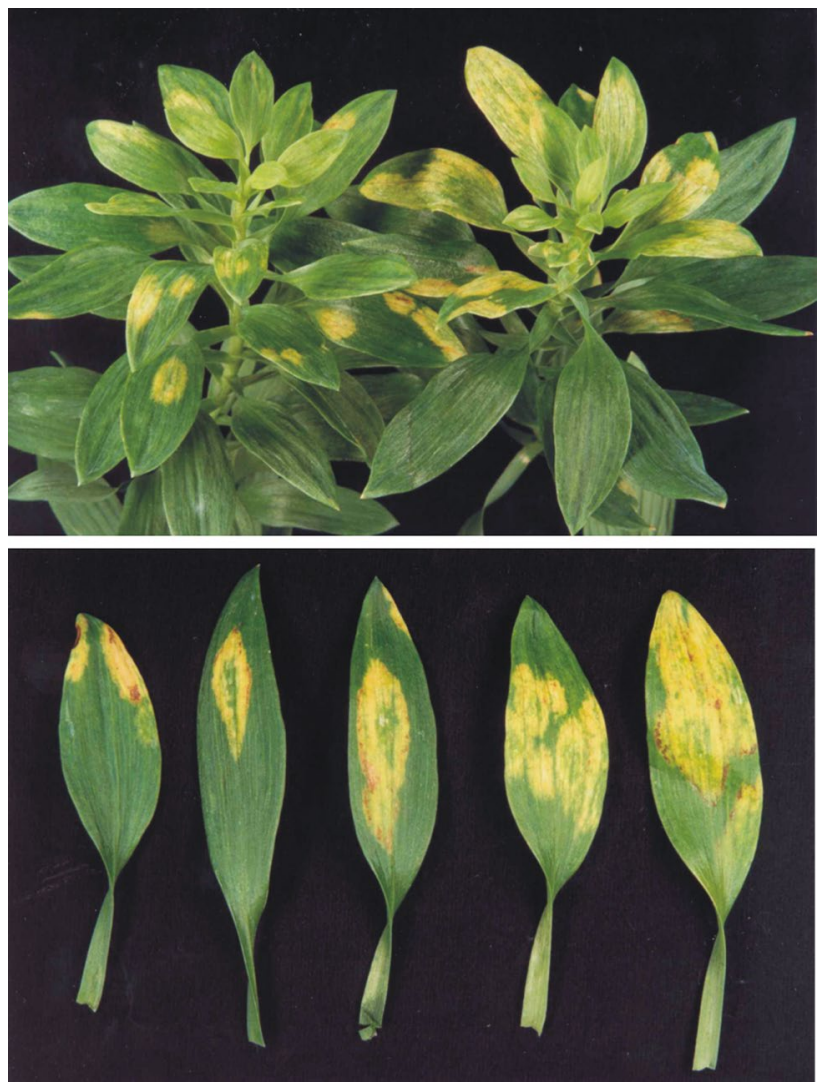

Fig. 1 Symptoms of alstromeria yellow spot virus (AYSV). Yellow spots on alstroemeria leaves of naturally infected plant

\section{Materials and methods}

\section{Virus source, virus isolates and host range}

Leaf material of suspected virus-infected (Als-2000) alstroemeria was homogenized in PBS buffer ( $\mathrm{pH}$ 7.0) with $0.01 \%$ sodium sulphite and mechanically inoculated to Nicotiana benthamiana. Orthotospovirus isolates TSWV BR-01 [19], tomato chlorotic spot virus (TCSV) BR-03 [19], groundnut ring spot virus (GRSV) SA-05 [19], IYSV-NL [45] and TYRV-t [46] used in serological studies, were also maintained on $N$. benthamiana. For a host range analysis, sap from Als-2000-infected alstroemeria leaf material was mechanically inoculated on 29 plant species (at least 2 plants/species) and monitored during 3-4 weeks for symptom expression.

\section{Ribonucleocapsid purification, SDS-PAGE and serological analysis}

Ribonucleocapsid protein (RNP) was purified from Als2000-infected N. benthamiana plants [47] and subjected 
to $25-45 \% \mathrm{CsSO}_{4}$ gradient centrifugation. RNP fractions collected were used to immunize rabbits for the production of a polyclonal antiserum. Prior to this, RNP fractions were subjected to a quality/purity check, in comparison to INSV and TSWV RNP preparations, on a 12\% SDS-PAGE after denaturation in Laemmli buffer [48]. Rabbits were immunized 2-3 times with $50-100 \mu \mathrm{g}$ of purified RNP emulsified with incomplete Freund's adjuvant $(1: 1, w / v)$, during intervals of two weeks. Serum was collected two weeks after the last injection and used for the purification of $\operatorname{IgG}$ and an the preparation of an IgG-alkaline-phosphatase conjugate. For orthotospovirus differentiation double-antibody sandwich-enzyme-linked immunosorbent assays (DAS-ELISA) were performed using a panel of polyclonal antisera raised against Als2000, TSWV, TCSV, GRSV, IYSV and TYRV [45-47]. Sap of infected and healthy $N$. benthamiana plants was diluted 1:30 and used as the antigen source and negative control, respectively.

\section{RNA purification and RT-PCR}

Viral RNA was purified either from purified RNPs using $1 \%$ SDS and hot phenol extraction followed by ethanol precipitation [9] or from infected plant material using Trizol buffer according to the manufacturer's instructions (Invitrogen).

In a first approach to obtain Als-2000 viral sequences only a single primer "Asian Termini" (AT; 5'-CCCGGA TCCAGAGCAATCGAG-3', containing a BamHI restriction site (underlined) and matching the 3' terminal sequences of Asian orthotospoviruses (italics), was used for firststrand cDNA synthesis using M-MLV Reverse Transcriptase (Promega), and a subsequent PCR amplification [46] using Phusion High-Fidelity DNA Polymerase (New England BioLabs). Since the sequence of the amplicon obtained using the AT primer showed highest homology with the $\mathrm{NS}_{\mathrm{M}}$ gene of IYSV, a second approach was applied in which Als-2000 sequences were additionally RT-PCR amplified using primers IY1 (5'-CCCGAGGA TCCATGGCTACCGTTAGGG-3') and IY2 (5'-CCCGA GGATCCAAATTAATTATATCTATCTTTCTTGG-3') corresponding to IYSV $\mathrm{N}$ gene sequences (in italics) combined with the universal hairpin primer (UHP) (5'-CACT GGATCCTTTTGTTTTTGTTTTTTG-3') as described before $[45,46]$. Based on newly obtained sequences for Als-2000, specific primers were designed to verify/ obtain additional sequences to complete the entire S RNA nucleotide sequence. Primers Als2000-NS $\mathrm{N}_{\mathrm{M}} \mathrm{R}$ (5'-GCT TGGTTTTCTTTCTTTTTCCTTC-3') and Als2000-G-R (5'-CCTCCTAAAACATATGACTTTCC-3') were used to amplify the 5 ' ends of the $\mathrm{NS}_{\mathrm{M}}$ respectively $\mathrm{G}_{\mathrm{N}} / \mathrm{G}_{\mathrm{C}}$ glycoprotein precursor ORFs in combination with the AT termini primer. In analogy to the approach for the S RNA segment, new and specific primers were designed to verify and/or obtain sequences for the intergenic region of the $\mathrm{M}$ RNA segment. All PCR fragments obtained were cloned into pJET blunt 1.2 vector (Fermentas) and their sequences determined (Eurofins).

\section{Sequence analysis of $S$ and M RNA segments}

Contigs for the M and S RNA segments were assembled from obtained sequences using DNAStar software and used to search the GenBank database using BLASTn and BLASTp. Multiple sequence alignment and phylogenetic analysis were performed using MEGA 7 software [49]. The $\mathrm{G}_{\mathrm{N}}-\mathrm{G}_{\mathrm{C}}$ sequence was analyzed for the presence of $\mathrm{N}$ - and O-linked glycosylation sites by prediction using the NetNGlyc 1.0 and NetOGlyc 3.1 Servers (http://www.cbs.dtu.dk/ services/NetNGlyc/; http://www.cbs.dtu.dk/services/NetOG lyc-3.1/). Potential signal cleavage sites within the glycoprotein were predicted using the SignalP 4.1 server (http:// www.cbs.dtu.dk/services/SignalP/). Transmembrane regions within the $\mathrm{G}_{\mathrm{N}}-\mathrm{G}_{\mathrm{C}}$ precursor protein were predicted using the TMHMM Server v.2.0 program (http://www.cbs.dtu.dk/servi ces/TMHMM/).

\section{Sequences analysis of Als-2000 by Next Generation Sequencing}

For the sequencing of the entire Als-2000 genome using next generation sequencing (NGS) technology, total RNA was isolated from systemically infected $N$. benthamiana leaves with the Qiagen RNeasy plant mini kit according the manufacturers' procedures (Qiagen). Samples were prepared for HighSeq sequencing according to Verbeek et al. [50]. Sequence data were analyzed using the CLC Genomics Workbench 8.5.1 (Qiagen) as earlier described [51]. To obtain and verify the full length sequence of Als-2000 the 5'- and 3'-ends of the viral RNA segments and regions from which only few reads were obtained, were RT-PCR amplified with specific primers and directly sequenced by Sanger sequencing (Macrogen).

\section{Thrips transmission}

To determine the potential of Thrips tabaci for transmission of Als-2000, 10 first and early second instar larvae of $T$. tabaci were given an acquisition period of $24 \mathrm{~h}$ on Als-2000 infected Emilia sonchifolia and next transferred to healthy E. sonchifolia plants. Plants were kept under cages at room temperature and monitored for symptom expression for two weeks. The presence of Als-2000 in plants was tested by RT-PCR using primers IY1 and IY2. Fragments of expected 
sizes were collected and the AYSV sequence confirmed by sequence analysis.

\section{Results}

\section{Host range analysis}

From 31 plant species mechanically inoculated with Als2000, from here onwards referred to as alstroemeria yellow spot virus (AYSV), 17 species did not show any sign of infection, 9 species only showed local symptoms while 5 species displayed local and systemic symptoms (Table 1). Back-inoculation of the isolate from $N$. benthamiana on the alstroemeria cultivar Dimention did not induce any symptoms. The data indicated that the virus had a relatively narrow host range and among the plants tested only dicots showed local or systemic symptoms.

\section{N protein electrophoresis and DAS-ELISA}

To comparatively analyze AYSV and serologically differentiate this virus from other orthotospoviruses, AYSV RNPs were purified and analyzed by SDS-PAGE. A major band of approximate $\mathrm{M}_{\mathrm{W}} 30 \mathrm{kDa}$ migrated at a position in between the INSV and TSWV N proteins and likely represented the AYSV N protein (Figure 2, left panel). Polyclonal antibodies produced against the AYSV RNPs were used to analyze its serological relationship to a set of orthotospoviruses. In DAS-ELISA, only leaf extracts of AYSV-infected plants reacted positively with polyclonal antiserum against AYSV, while no positive reaction was observed with antisera raised against other orthotospovirus species (Figure 2, right panel).

\section{Sequence analysis and characterization of the $S$ RNA, M RNA and L RNA}

The entire sequence of AYSV S RNA consisted of 2734 nucleotides (nt) with $5^{\prime}$ terminal (72 nt) and $3^{\prime}$ terminal (71 nt) untranslated regions (UTR) that contain the highly conserved 8 terminal nucleotides present in all orthotospovirus RNA genome segments. AYSV terminal sequences show almost entire base pair complementarity of the first $18 \mathrm{nt}$ with only 3 base pair mismatches (5'-AGAGCA AUCGNNGNAUAA-3'). This complementarity continues, although to a lesser extent, to $\sim 60$ nucleotides of the UTR sequences and assists in the panhandle formation of the $\mathrm{S}$ RNA segment.

The TYRV S RNA contains a vORF starting with an AUG at nucleotide position 73 and terminating with a UAG codon at position 1404, coding for 443 residues of the $\mathrm{NS}_{\mathrm{S}}$ protein with a predicted molecular mass of $50.1 \mathrm{kDa}$. The
Table 1 Host range study of AYSV (Als-2000 isolate) via mechanical inoculation

\begin{tabular}{|c|c|c|}
\hline \multirow[t]{2}{*}{ Plant family and species } & \multicolumn{2}{|l|}{ Symptom } \\
\hline & Local & Systemic \\
\hline \multicolumn{3}{|l|}{ Alstroemeriaceae } \\
\hline Alstroemeria sp. cv. Dimension & - & - \\
\hline \multicolumn{3}{|l|}{ Amaranthaceae } \\
\hline Gomphrena globosa & - & - \\
\hline \multicolumn{3}{|l|}{ Amaryllidaceae } \\
\hline Allium porrum & - & - \\
\hline Hippeastrum sp. cv. Orange Souvereigh & - & - \\
\hline Hippeastrum sp. cv. Red Lion & - & - \\
\hline \multicolumn{3}{|l|}{ Asteraceae } \\
\hline Emilia sonchifolia & $\mathrm{CS}, \mathrm{NS}$ & CS, NS \\
\hline Zinnia elegance & - & - \\
\hline \multicolumn{3}{|l|}{ Balsaminaceae } \\
\hline Impatiens sp. & NL,NR,N & - \\
\hline \multicolumn{3}{|l|}{ Chenopodiaceae } \\
\hline Chenopodium amaranticolor & - & - \\
\hline Chenopodium quinoa & - & - \\
\hline \multicolumn{3}{|l|}{ Cucurbitaceae } \\
\hline Cucumis sativus cv. Hokus & - & - \\
\hline Cucurbita pepo cv. Black Beauty & - & - \\
\hline \multicolumn{3}{|l|}{ Fabaceae } \\
\hline Arachis hypogea & - & - \\
\hline Vicia faba cv. Wikiem Majort & NL & - \\
\hline Vigna unguiculata cv. Black Eye & $\mathrm{NL}$ & - \\
\hline Vigna unguiculata cv. Early Red & CL,NL & $\mathrm{S}$ \\
\hline Phaseolus vulgaris cv. Pinto & NL & - \\
\hline \multicolumn{3}{|l|}{ Iridaceae } \\
\hline Iris hollandicum cv. Blue Magic & - & - \\
\hline \multicolumn{3}{|l|}{ Solanaceae } \\
\hline $\begin{array}{l}\text { Capsicum аппиит cv. Westlandse Grote } \\
\text { Zoete }\end{array}$ & - & - \\
\hline Datura metel & NL & - \\
\hline Datura stramonium & NL & - \\
\hline Physalis floridana & - & - \\
\hline Pisum sativum & - & - \\
\hline Nicotiana benthamiana & $\mathrm{CL}$ & $\mathrm{CS}, \mathrm{NS}, \mathrm{C}, \mathrm{RG}$ \\
\hline Nicotiana clevelandii & $\mathrm{C}, \mathrm{N}$ & $\mathrm{C}, \mathrm{N}, \mathrm{RG}$ \\
\hline Nicotiana glutinosa & NL & - \\
\hline Nicotiana hesperis-67A & CL,NL & NL \\
\hline Nicotiana occidentalis-P1 & NL & - \\
\hline Nicotiana rustica & - & - \\
\hline Nicotiana tabacum cv. White Burley & NL,NR & - \\
\hline Solanum lycopersicum cv. Money Maker & - & - \\
\hline
\end{tabular}

$C$ chlorosis; $L C$ leaf curling; $C L$ Chlorotic lesions; $C S$ Chlorotic spot; $N$ necrosis; NL necrotic lesions; NR necrotic rings; NS necrotic spots; $R G$ retardation in growth; $S$ symptomless infection 


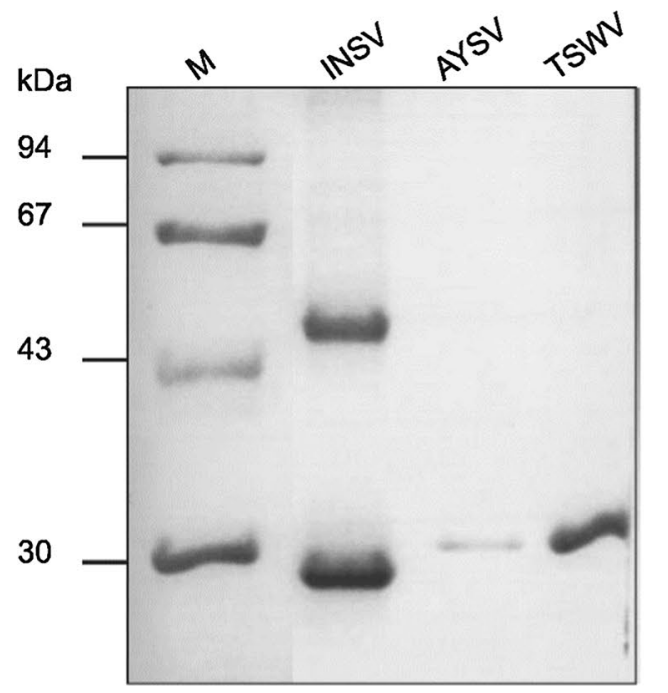

Fig. 2 Analysis of the major structural N protein from purified AYSV RNPs and serology. Purified AYSV RNPs were comparatively analyzed to those of TSWV and INSV on SDS-PAGE (left panel). Proteins were stained with Coomassie Brilliant Blue. Size marker is indi- cated at the left side of the gel. Serological differentiation between AYSV and five orthotospoviruses in DAS-ELISA (right panel) was performed using polyclonal antisera raised against respective $\mathrm{N}$ proteins and the extracts from infected plants as antigen source
vcORF starts with an AUG at nucleotide position 2663 and terminates with a UAA stop codon at nucleotide position 1845 , coding for 272 residues of the $\mathrm{N}$ protein with a predicted molecular mass of $30.1 \mathrm{kDa}$. A noncoding intergenic region (IGR) encompassess nucleotide position 1405 to 1844 and is highly rich in stretches of A and $\mathrm{U}$ residues, enabling the putative formation of a hairpin structure (data not shown).

Upon multiple sequence alignment of the AYSV N protein to other orthotospoviral $\mathrm{N}$ proteins, AYSV $\mathrm{N}$ showed highest identity (69.5\%) with polygonum ringspot virus (PolRSV). This homology is well below the threshold for demarcation of new orthotospovirus species and indicated that AYSV tentatively presents a new distinct species. In a phylogenetic analysis based on the N protein, AYSV clusters together with members initially found in Europe and Asia that belong to the so-called Eurasian clade. A similar phylogenetic analysis using AYSV $\mathrm{NS}_{\mathrm{S}}$ revealed $88.3 \%$ identity to that of TYRV, and supports the relationship of AYSV to the Eurasian clade (Figure 3).

The complete nucleotide sequence of AYSV M RNA consists of $4797 \mathrm{nt}$, and contains a 5'- (62 nt) and 3'-UTR (51 nt) that is able to form a panhandle structure due to sequence complementarity. The UTRs show almost entire sequence complementarity for $29 \mathrm{nt}$ with only 3 mismatches (5'-AGAGCAAUCGGUGCAANAAUCAAAUNUNU-3'). The vORF starts with an AUG at nucleotide position 63 and terminates with an UAA codon at position 989, coding for the $\mathrm{NS}_{\mathrm{M}}$ protein with a predicted molecular mass of $34.2 \mathrm{kDa}$. The AYSV $\mathrm{NS}_{\mathrm{M}}$ protein shows conserved motifs that belong to the $30 \mathrm{~K}$ movement protein superfamily [52,
53], including $\mathrm{D}_{155}, \mathrm{G}_{211}$ and P/D-L-X (amino acid residues $\mathrm{D}_{102} \mathrm{~S}_{103} \mathrm{~L}_{104}$ ), and motifs for a phospholipase A2 catalytic site and PLA2 (amino acid residues CMQLNLTS ${ }_{[197-204]}$ ).

The vcORF codes for the glycoprotein precursor and starts with an AUG codon at nucleotide position 4746 and terminates with UGA at nucleotide position 1300 . The M RNA encoding v- and vc-ORFs flank an IGR of $310 \mathrm{nt}$ that runs from nucleotide position 990 to 1299 and, like the S RNA, consists of nucleotide stretches highly rich in A- and $\mathrm{U}$ residues. Folding predictions of the IGR sequence reveals the formation of a stable hairpin structure (data not shown).

Using BLASTp, the highest identity of AYSV $\mathrm{NS}_{\mathrm{M}}$ was found with TYRV $\mathrm{NS}_{\mathrm{M}}(88.7 \%)$ whereas its glycoprotein precursor (GP) showed highest identity with that of TYRV GP $(81.0 \%)$. Phylogenetic analysis based on the $\mathrm{NS}_{\mathrm{M}}$ protein and the glycoprotein precursor support a classification of AYSV within the Eurasian clade (Figure 3).

The surface glycoprotein of AYSV was analyzed and compared to those of other Eurasian orthotospovirus species for the presence of $\mathrm{N}-$, O- Glycosylation, peptide cleavage sites and transmembrane domains (Figure 4). Two putative N-glycosylation sites, $\mathrm{Asn}_{319}$ and $\mathrm{Asn}_{575}$ and eight O-glycosylation sites i.e. $\mathrm{Thr}_{80}, \mathrm{Thr}_{82}, \mathrm{Thr}_{84}, \mathrm{Thr}_{99}, \mathrm{Thr}_{100}$, $\mathrm{Thr}_{101}, \mathrm{Thr}_{102}$ and $\mathrm{Thr}_{105}$ were predicted. Two signal peptide sequences with predicted cleavage sites were found at amino acid positions $\mathrm{Leu}_{23}$ and $\mathrm{Leu}_{462}$. Five (hydrophobic) transmembrane domains were found in the $\mathrm{G}_{\mathrm{N}}-\mathrm{G}_{\mathrm{C}}$ precursor. Both of the predicted cleavage sites located within the first and fourth transmembrane domains, whereas none of the predicted glycosylation sites mapped within transmembrane domains (Figure 4). A comparison to the $\mathrm{G}_{\mathrm{N}}-\mathrm{G}_{\mathrm{C}}$ precursor 

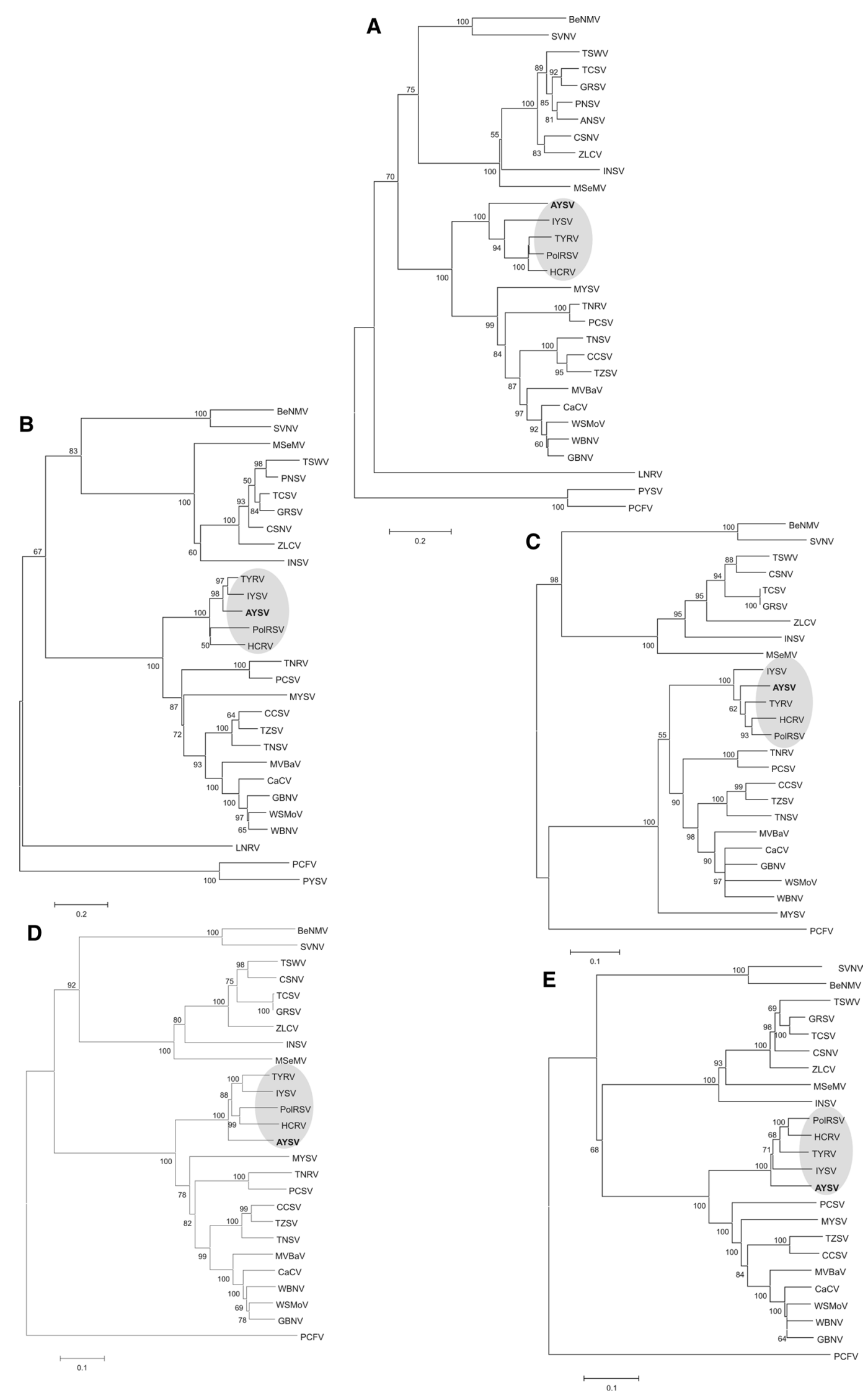
4Fig. 3 Phylogenetic relationships of alstroemeria yellow spot virus (AYSV) proteins and those of the other tentative and established orthotospovirus species. The trees were inferred based on the alignments of amino acid sequences of the nucleocapsid (N) proteins (A), RNA silencing suppressor $\left(\mathrm{NS}_{\mathrm{S}}\right)$ proteins $(\mathrm{B})$, cell-to-cell movement $\left(\mathrm{NS}_{\mathrm{M}}\right)$ proteins $(\mathrm{C})$, precursor Glyco $\left(\mathrm{G}_{\mathrm{N}}-\mathrm{G}_{\mathrm{C}}\right)$ proteins $(\mathrm{D})$ and $\mathrm{RdRp}$ (L) proteins (E) from alstroemeria necrotic streak virus (ANSV), capsicum chlorosis virus ( $\mathrm{CaCV}$ ), calla lily chlorotic spot virus (CCSV), chrysanthemum stem necrosis virus (CSNV), groundnut bud necrosis virus (GBNV), groundnut ringspot virus (GRSV), impatiens necrotic spot virus (INSV), iris yellow spot virus (IYSV), lisianthus necrotic ringspot virus (LNRV), melon severe mosaic virus (MeSMV), melon yellow spot virus (MYSV), peanut chlorotic fan-spot virus (PCFV), peanut yellow spot virus (PYSV), polygonum ringspot virus (PolRSV), tomato chlorotic spot virus (TCSV), tomato necrotic spot virus (TNSV), tomato spotted wilt virus (TSWV), tomato yellow ring virus (TYRV), tomato zonate spot virus (TZSV), watermelon bud necrosis virus (WBNV), watermelon silver mottle virus (WSMoV) and zucchini lethal chlorosis virus (ZLCV) and AYSV (this report). The trees were constructed using the neighbour-joining method implemented in MEGA7.0. Bootstrap values are shown as percentages derived from 1,000 replicates. Those values less than $50 \%$ are not shown. GenBank accession numbers of the viral genome sequences from which the viral protein sequences were taken are listed in table $\mathrm{S} 2$

of other Eurasian orthotospovirus species revealed that the AYSV precursor contains the lowest number of N-glycosylation sites and the highest number of O-glycosylation sites. Based on the predicted cleavage sites, the AYSV G $\mathrm{G}_{\mathrm{N}}-\mathrm{G}_{\mathrm{C}}$ precursor is processed into the mature $\mathrm{G}_{\mathrm{N}}$ and $\mathrm{G}_{\mathrm{C}}$ glycoproteins of 50.3 and $77.4 \mathrm{kDa}$, respectively (Figure 4). The AYSV $\mathrm{G}_{\mathrm{N}}-\mathrm{G}_{\mathrm{C}}$ precursor does not contain a Arg-Gly-Asp (RGD) sequence, a motif earlier found in the TSWV precursor and putatively involved in virus cell attachment [9].

The entire sequence of AYSV L RNA consists of 8865 nt with a 5' terminal (214 nt) and $3^{\prime}$ terminal (32 nt) UTR that contain the highly conserved 8 terminal nucleotides present in all orthotospoviral RNA segments. AYSV terminal sequences show almost entire base pair complementarity for the first 16 nt with only one base pair mismatch (5'-AGA GCAAUCNAGCAAC-3').

The L RNA contains a single ORF of 8619 nt in the vcstrand and coding for the putative viral RNA-dependent RNA polymerase (RdRp, L protein) of 2873 aa with a predicted molecular mass of $316.0 \mathrm{kDa}$. The vcORF starts with an AUG at nucleotide position 8833 and terminates with an UAA stop codon at nucleotide position 212 . The $\mathrm{L}$ gene of AYSV shares highest aa $(87.3 \%)$ identity with the one from TYRV. Analysis of the AYSV L protein revealed the presence of all conserved motifs earlier reported and indicative for the $\operatorname{RdRp}[54,55]$. The highly conserved region, shared among all characterized orthotospoviral L proteins, is found at aa position 1,275-1,559 of the AYSV L protein. This region contains the essential motifs of viral RdRp proteins from negative strand RNA viruses and includes motif A (aa 1,365-1,378), motif B (aa 1,452-1,471), motif
C (aa 1,490-1,499), motif D (aa 1,534-1,544), motif E (aa 1,547-1,559), and motif F (aa 1,275-1,301) [54, 55]. The AYSV RdRp motif sequences are $100 \%$ identical to those of TYRV. Phylogenetic analysis of the RdRp shows a clustering of AYSV with TYRV, PolRSV, hippeastrum chlorotic ringspot virus (HCRV) and IYSV (Figure 3).

A summary and comparative analysis of the AYSV L, M and S RNA sequence to those of other Eurasian species is shown in Table 2. While the L RNA sequence has not been elucidated for all Eurasian species, the structural features of the M and S RNA of AYSV show highest similarity to those from PolRSV, the closest related species, with the exception of a differently sized IGR within the $\mathrm{S}$ segment (AYSVIGR $_{478}$ Vs. PolRSV-IGR ${ }_{183}$ ).

The complete L, M and S RNA sequences of AYSV are available under GenBank accession no. MF469033, MF469034 and MF469035 respectively

\section{Vector transmission}

Healthy E. sonchifolia plants exposed to T. tabaci, that in their larval stages were given access to AYSV-infected plants, revealed chlorotic spots similar to those observed earlier during the host range analyses (Table 1). The presence of AYSV was confirmed and successful transmission by viruliferous thrips was demonstrated by RT-PCR amplification of (partial) AYSV N gene sequences from infected leaf material and subsequent sequence analysis.

\section{Discussion}

Here a tentative new orthotospovirus species has been identified and characterized from alstroemeria, and for which the name alstroemeria yellow spot virus (AYSV) has been proposed. The virus causes yellow spots on alstroemeria, has a narrow experimental host range limited to a few dicots and is transmitted by the vector T. tabaci. A polyclonal antiserum has been raised against AYSV RNPs and only reacts positively with the homologous virus and not with any other established orthotospovirus species tested. The nucleotide sequence of the genomic L, M and S RNA segments has been elucidated (8619, 4797 and 2734 nt, respectively) and contains 5 ORFs coding for six mature proteins i.e., the $\mathrm{L}$ protein (viral RdRp, $316 \mathrm{kDa}$ ), the cell-to-cell movement protein $\left(\mathrm{NS}_{\mathrm{M}}, 34.2 \mathrm{kDa}\right)$, the precursor $(127,7 \mathrm{kDa})$ to the glycoproteins $\mathrm{G}_{\mathrm{N}}$ and $\mathrm{G}_{\mathrm{C}}$, the suppressor of RNA silencing $\left(\mathrm{NS}_{\mathrm{S}}, 50.1 \mathrm{kDa}\right)$ and the nucleocapsid protein $(\mathrm{N}, 30.1$ $\mathrm{kDa}$ ). The AYSV sequence shows all structural features typical for orthotospovirus RNA genomes with highest homology between its proteins and those from TYRV. Phylogenetic analysis indicates that AYSV, together with PolRSV, TYRV, HCRV and IYSV, belongs to a growing clade of 
Fig. 4 Topology of the glycoprotein precursor of AYSV in comparison to the ones from other Euroasian orthotospoviruses. Predicted glycosylation sites are indicated with arrows op top. Hydrophobic domains representing signal sequences and transmembrane domains are indicated in grey, and their locations within the precursor with the position of amino acids below. Predicted cleavage sites for maturation of the precursor into the mature $G_{N}$ and $G_{C}$ glycoproteins are indicated with scissors with the amino acids sequence of the cleavage sites above it (TEV-L and SLA-L, respectively)
AYSV
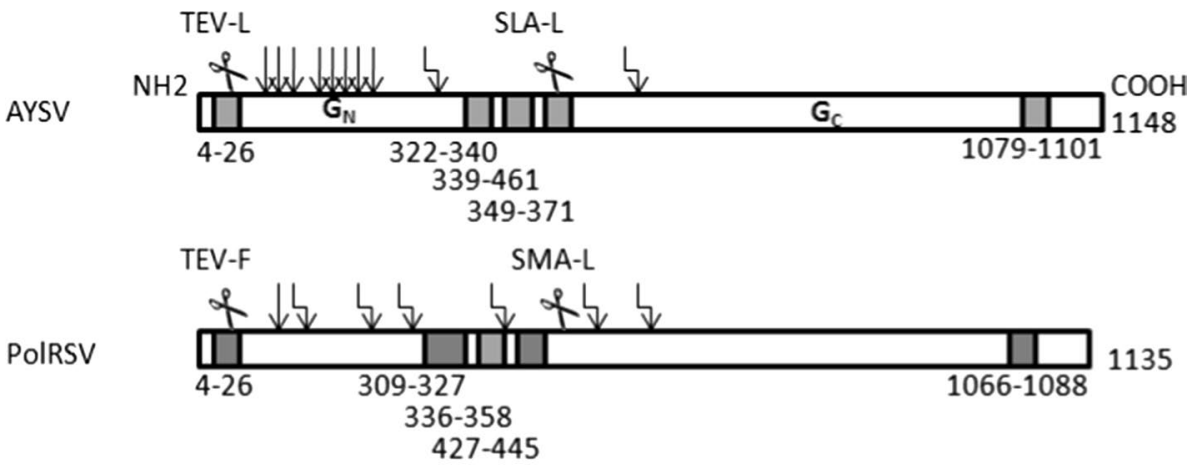

1135

TYRV

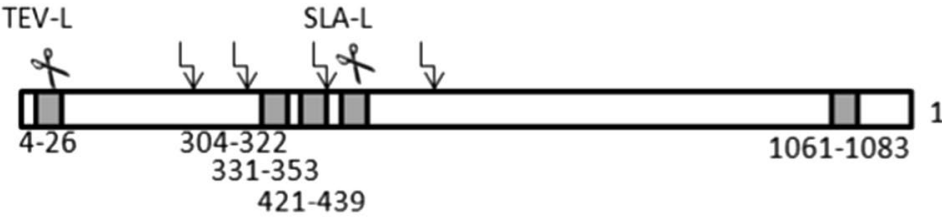
1130

IYSV

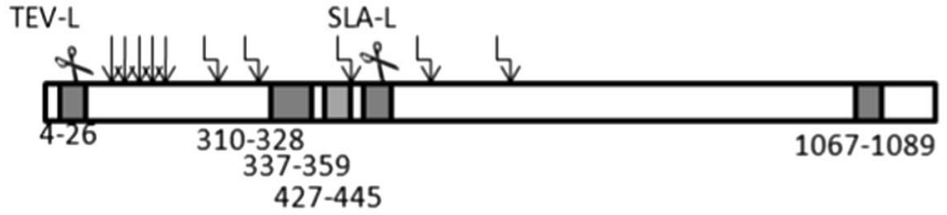
1136

HCRV

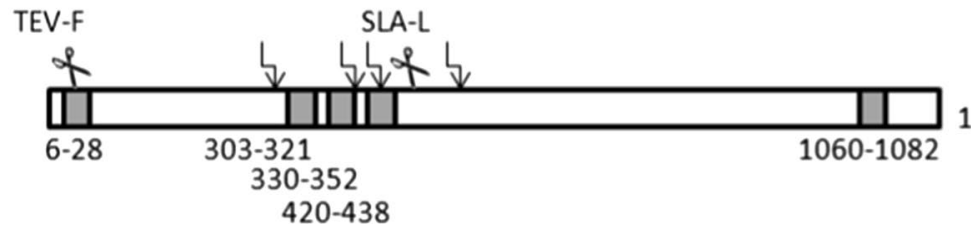

Table 2 Comparison of structural features of the L, M and S RNA segments of AYSV to those of other Eurasian orthotospoviruses

\begin{tabular}{|c|c|c|c|c|c|}
\hline Virus acronym & AYSV & PolRSV & TYRV & IYSV & HCRV \\
\hline S RNA* & 2,734 & 2,484 & 3,061 & 3,105 & 2,744 \\
\hline 5' UTR* & 72 & 72 & 71 & 70 & 73 \\
\hline $\mathrm{NS}_{\mathrm{S}} * *$ & 443 & 443 & 443 & 443 & 445 \\
\hline IGR* & 440 & 183 & 762 & 811 & 437 \\
\hline $\mathrm{N}^{* *}$ & 272 & 274 & 274 & 273 & 274 \\
\hline 3' UTR* & 71 & 72 & 71 & 70 & 71 \\
\hline M RNA* & 4,797 & 4,710 & 4,786 & 4,838 & 4,741 \\
\hline${ }^{\prime}$ ' UTR* & 62 & 62 & 62 & 63 & 47 \\
\hline $\mathrm{NS}_{\mathrm{M}} * *$ & 308 & 308 & 308 & 311 & 308 \\
\hline $\mathrm{IGR}^{*}$ & 310 & 263 & 354 & 379 & 330 \\
\hline $\mathrm{G}_{\mathrm{N}}-\mathrm{G}_{\mathrm{C}} * *$ & 1,148 & 1,135 & 1,130 & 1,136 & 1,129 \\
\hline 3' UTR* & 51 & 50 & 50 & 49 & 47 \\
\hline L RNA & 8865 & 8893 & 8877 & 8880 & 8908 \\
\hline $5^{\prime} \mathrm{UTR}^{*}$ & 211 & 230 & 223 & 225 & 253 \\
\hline $\mathrm{RdRp} * *$ & 2,873 & 2,876 & 2,873 & 2,873 & 2873 \\
\hline 3' UTR* & 32 & 32 & 32 & 33 & 33 \\
\hline
\end{tabular}

* Number of nucleotide residue; ** Number of amino acid residue orthotospoviruses for which the geographical origin seems to be based in the Middle-East [46]. Although the origin of the virus-infected alstroemeria plant could not be indicated with certainty, it was provided by a grower that at that time had simultaneously received shipments of alstroemeria plants from Colombia and Iran. Considering the relation of AYSV to the orthotospoviruses from the Middle-East cluster makes it most likely that Iran is the site of origin of the collected sample.

With the identification of this new orthotospovirus species, the family of Tospoviridae is still expanding and has currently reached the number of 30 tentative and established species ([2] and, this report). While this new species has only a small (experimental) host range, its natural host species so far is limited to alstroemeria. With the availability of a specific polyclonal antiserum to AYSV, field surveys could help to identify other natural (cultivated and non-cultivated) plant hosts of this virus. Considering that nothing is known on the prevalence and distribution of AYSV in agricultural and horticultural crops and ornamentals these surveys will also indicate the economic importance of this virus.

During this study a combination of conventional and NGS sequencing approaches has helped to elucidate the entire AYSV genome sequence. The speed and complete data sets 
obtained by the NGS approach, combined with lowering costs, favor usage of NGS for the elucidation of viral RNA/ DNA genomes. However, during this study and our earlier sequence analysis of chrysantemum stem necrosis virus (CSNV) [51] we have observed that the NGS approach may not always provide the entire 5' and 3' -terminal sequences and sufficient reads to span the entire A- and U-rich intergenic region. Assembly of the latter reads into one contig is also hampered by the fact that they are relatively short and subsequently fail to properly assemble due to sequence stretches rich in A- and U-residues. Verification of the termini and intergenic region thus still needs to be done by conventional RT-PCR / 5' and 3' RACE amplification and Sanger sequence analysis of the amplicons.

Acknowledgements The authors thank Janneke Saaijer and Francis Makamba for their preliminary biological and serological study of this virus. This research was partly funded by the Dutch Ministry of Economic Affairs in the Topsector Program "Horticulture and Starting Materials" under theme "Fytosanitary Fundament".

\section{Compliance with ethical standards}

Conflict of interest The authors declare to have no conflict of interest.

Ethical approval This article does not contain any studies with human participants or animals performed by any of the authors.

Open Access This article is distributed under the terms of the Creative Commons Attribution 4.0 International License (http://creativeco mmons.org/licenses/by/4.0/), which permits unrestricted use, distribution, and reproduction in any medium, provided you give appropriate credit to the original author(s) and the source, provide a link to the Creative Commons license, and indicate if changes were made.

\section{References}

1. Pappu HR, Jones RAC, Jain RK (2009) Global status of tospovirus epidemics in diverse cropping systems: successes achieved and challenges ahead. Virus Res 141:219-236

2. Turina M, Kormelink R, Resende RO (2016) Resistance to tospovirusus in vegetable crops: epidemiological and molecular aspects. Annu Rev Phytopathol 54:347-371

3. Goldbach R, Peters D (1994) Possible causes of the emergence of tospovirus diseases. Semin Virol 5:113-120

4. Scholthof K-BG, Adkins S, Czosnek H, Palukaitis P, Jacquot E, Hohn T, Hohn B, Saunders K, Candresse T, Ahlquist P, Hemenway C, Foster GD (2011) Top 10 plant viruses in molecular plant pathology. Mol. Plant Pathol 12:938-954

5. Rybicki E (2015) A Top Ten list for economically important plant viruses. Arch Virol 160:17-20

6. Kormelink R (2011) The molecular biology of tospoviruses and resistance strategies. In: Elliott RM, Plyusin A (eds) The bunyaviridae. Plenum Press, New York

7. Bragard C, Caciagli P, Lemaire O, Lopez-Moya JJ, MacFarlane S, Peters D, Susi P, Torrance L (2013) Status and prospects of plant virus control through interference with vector transmission. Annu Rev Phytopathol 51:177-201

8. Cortez I, Aires A, Pereira A-M, Goldbach R, Peters D, Kormelink R (2002) Genetic organisation of Iris yellow spot virus M RNA: indications for functional homology between the G(c) glycoproteins of tospoviruses and animal-infecting bunyaviruses. Arch Virol 147:2313-2325

9. Kormelink R, De Haan P, Meurs C, Peters D, Goldbach R (1992) The nucleotide sequence of the M RNA segment of tomato spotted wilt virus: a bunyavirus with two ambisense RNA segments. J Gen Virol 73:2795-2804

10. Kormelink R, Storms M, Van Lent J, Peters D, Goldbach R (1994) Expression and subcellular location of the $\mathrm{NS}_{\mathrm{M}}$ protein of tomato spotted wilt virus (TSWV), a putative viral movement protein. Virology 200:56-65

11. Storms MMH, Kormelink R, Peters D, Van Lent JWM, Goldbach RW (1995) Indications for a tubule guided cell-to-cell movement mechanism for tomato spotted wilt virus. Virol 214:485-493

12. Peters D (2008) Thrips as unique vectors of tospoviruses. Entomol Ber 68(5):182-186

13. Whitfield AE, Falk BW, Rotenberg D (2015) Insect vector mediated transmission of plant viruses. Virol 479:278-289

14. de Haan P, Wagemaker L, Peters D, Goldbach R (1990) The S RNA segment of Tomato spotted wilt virus has an ambisense character. J Gen Virol 71:1001-1007

15. Takeda A, Sugiyama K, Nagano H, Mori M, Kaido M, Mise K, Tsuda S, Okuno T (2002) Identification of a novel RNA silencing suppressor, NSs protein of Tomato spotted wilt virus. FEBS Lett 532:75-79

16. Bucher E, Sijen T, de Haan P, Goldbach R, Prins M (2003) Negative-strand tospoviruses and tenuiviruses carry a gene for a suppressor of gene silencing at analogous genomic positions. J Virol 77:1329-1336

17. Kormelink R, Kitajima EW, De Haan P, Zuidema D, Peters D, Goldbach R (1991) The nonstructural protein (NSs) encoded by the ambisense S RNA segment of tomato spotted wilt virus is associated with fibrous structures in infected plant cells. Virol 181:459-468

18. Margaria P, Bosco L, Vallino M, Ciuffo M, Mautino GC, Tavella L, Turina M (2014) The NSs protein of tomato spotted wilt virus is required for persistent infection and transmission by Frankliniella occidentalis. J Virol 88:5788-5802

19. de Ávila AC, de Haan P, Smeets MLL, Resende RO, Kormelink R, Kitajima E, Goldbach R, Peters D (1992) Distinct levels of relationships between tospovirus isolates. Arch Virol 128:211-227

20. Plyusnin A, Beaty BJ, Elliott RM, Goldbach R, Kormelink R, Lundkvist A, Schmaljohn CS, Tesh RB (2012) Bunyaviridae. In: King AMQ, Adams MJ, Carstens EB, Lefkowitz EJ (eds) Virus taxonomy: ninth report of the international committee on taxonomy of viruses. Elsevier Academic Press, San Diego, pp 725-741

21. Yin Y, Zheng K, Dong J, Fang Q, Wu S, Wang L, Zhang Z (2014) Identification of a new tospovirus causing necrotic ringspot on tomato in China. Virol J 11:213

22. Cheng YH, Zheng YX, Tai CH, Yen JH, Chen YK, Jan FJ (2014) Identification, characterisation and detection of a new tospovirus on sweet pepper. Ann Appl Biol 164:107-115

23. Shimomoto Y, Kobayashi K, Okuda M (2014) Identification and characterization of Lisianthus necrotic ringspot virus, a novel distinct tospovirus species causing necrotic disease of lisianthus (Eustoma grandiflorum). J Gen Plant Pathol 80:169-175

24. Meng J, Liu P, Zhu L, Zou C, Li J, Chen B (2015) Complete genome sequence of mulberry vein banding associated virus, a new tospovirus infecting mulberry. PLoS One 10:e0136196

25. Dong JH, Yin YY, Fang Q, McBeath JH, Zhang ZK (2013) A new tospovirus causing chlorotic ringspot on Hippeastrum sp in China. Virus Genes 46:567-570 
26. Wu PR, Chien WC, Okuda M, Takeshita M, Yeh SD, Wang YC, Chen TC (2015) Genetic and serological characterization of chrysanthemum stem necrosis virus, a member of the genus Tospovirus. Arch Virol 160:529-536

27. Gera A, Zeidan M (2006) New and emerging virus diseases in ornamental crops. Acta Hortic 722:175-180

28. Kim JB (2005) Development of efficient regeneration and transformation systems in Alstroemeria. PhD Dissertation. Wageningen University \& Research, The Netherlands, p 160

29. Spence NJ, Mills PR, Barbara DJ (2000) A survey of viruses of Alstroemeria in the UK and the characterisation of carlaviruses infecting Alstroemeria. Eur J Plant Pathol 106:843-847

30. Bellardi MG, Bertaccini A, Betti L (1994) Survey of viruses infecting Alstroemeria in Italy. Acta Hort 377:73-80

31. van Zaayen A (1995) Alstroemeria. In: Loebenstein G, Lawson $\mathrm{RH}$, Brunt AA (eds) Virus and virus-like diseases of bulb and flower crops. Wiley, Chichester, pp 237-249

32. Fuji S-I, Mochizuki N, Fujinaga M, Ikeda M, Kouichi S, Seiji U, Hiromitsu F, Hideki N, Fumiyoshi F (2007) Incidence of viruses in Alstroemeria plants cultivated in Japan and characterisation of Broad bean wilt virus-2, Cucumber mosaic virus and Youcai mosaic virus. J Gen Plant Pathol 73:216-221

33. Verma N, Singh AK, Singh L, Raikhy G, Kulshrestha S, Singh MK, Hallan V, Ram R, Zaidi AA (2005) Cucumber mosaic virus (CMV) infecting Alstroemeria hybrids in India. Australas Plant Pathol 34:119-120

34. Hassani-Mehraban A, Botermans M, Verhoeven JThJ, Meekes E, Saaijer J, Peters D, Goldbach R, Kormelink R (2010) A distinct tospovirus causing necrotic streak on Alstroemeria sp. in Colombia. Arch Virol 155:423-428

35. Beikzadeh N, Bayat H, Jafarpour B, Rohani H, Peters D, HassaniMehraban A (2012) Infection of Alstroemeria plants to tomato yellow ring virus in Iran. J Phytopath 160:45-47

36. Cervantes-Díaz L, Zavaleta-Mejía E, Rojas-Martinez RI, Alanis-Martinez I, Ochoa-Martinez DL, Valadez-Moctezuma E, Grimaldo-Juarez O (2009) Detection of geminivirus associated to alstroemeria (Alstroemeria L.) in Villa Guerrero, State of Mexico/Deteccion de geminivirus asociados a la alstroemeria (Alstroemeria L.) en Villa Guerrero, Estado de Mexico/Deteccao de geminivirus associados a alstroemeria (Alstroemeria L.) em Villa Guerrero, Estado do Mexico. Interciencia 34(12):903

37. Phillips S, Brunt AA (1986) Four viruses of Alstroemeria in Britain. Acta Hort 177:227-234

38. Wong SM, Reiser RA, Horst RK (1992) A new virus in alstroemeria in the USA. Phytopathology 82:722

39. van Zaayen A, de Blank CM, Bouwen I (1994) Differentiation between two potyviruses in Alstroemeria. Eur J Plant Pathol 100:85-90

40. van der Vlugt RAA, Bouwen I (2002) Alstroemeria streak virus as an isolate of Alstroemeria mosaic potyvirus. Phytomedizin Deutsch Phytomedizinischen Ges V Sonderh 1:31
41. Bellardi MG, Vibio M, Bertaccini A (1992) Natural occurrence of Freesia mosaic virus in Alstroemeria sp. Plant Dis 76:643

42. Bouwen I, van der Vlugt RAA (2000) Natural infection of Alstroemeria caryophyllea with ornithogalum mosaic virus. Plant Dis 84(2):202

43. Bag S, Schwartz HF, Cramer CS, Havey MJ, Pappu HR (2015) Iris yellow spot virus (Tospovirus: Bunyaviridae): from obscurity to research priority. Mol Plant Pathol 16:224-237

44. Rasoulpour R, Izadpanah K (2007) Characterisation of cineraria strain of tomato yellow ring virus from Iran. Australas Plant Pathol 36:286-294

45. Cortês I, Livieratos IC, Derks A, Peters D, Kormelink R (1998) Molecular and serological characterization of Iris yellow spot virus, a new and distinct tospovirus species. Phytopathol $88: 1276-1282$

46. Hassani-Mehraban A, Saaijer J, Peters D, Goldbach R, Kormelink $\mathrm{R}$ (2005) A new tomato-infecting tospovirus from Iran. Phytopath 95:852-858

47. de Ávila AC, Huguenot C, Resende RO, Kitajima EW, Goldbach RW, Peters D (1990) Serological differentiation of 20 isolates of tomato spotted wilt virus. J Gen Virol 71:2801-2807

48. Laemmli UK (1970) Cleabage of structural proteins during the assembly of the head of bacteriophage T4. Nature 227:680-685

49. Kumar S, Stecher G, Tamura K (2016) MEGA7: molecular evolutionary genetics analysis version 7.0 for bigger datasets. Mol Biol Evol 33:1870-1874

50. Verbeek M, Dullemans AM, van Raaij HMG, Verhoeven JThJ, van der Vlugt RAA (2014) Lettuce necrotic leaf curl virus, a new plant virus infecting lettuce and a proposed member of the genus Torradovirus. Arch Virol 159:801-805

51. Dullemans AM, Verhoeven JThJ, Kormelink R, Van der Vlugt RAA (2015) The complete nucleotide sequence of chrysanthemum stem necrosis virus. Arch Virol 160:605-608

52. Li W, Lewandowski DJ, Hilf ME, Adkins S (2009) Identification of domains of the Tomato spotted wilt virus NSm protein involved in tubule formation, movement and symptomatology. Virology 390:110-121

53. Singh P, Indi SS, Savithri HS (2014) Groundnut bud necrosis virus encoded NSm associates with membranes via its C-terminal domain. PLoS One 9(6):e99370

54. Chen TC, Li JT, Fan YS, Yeh YC, Yeh SD, Kormelink R (2013) Molecular characterization of the full-length L and M RNAs of Tomato yellow ring virus, a member of the genus Tospovirus. Virus Genes 46:487-495

55. Amroun A, Priet S, de Lamballerie X, Quérat G (2017) Bunyaviridae RdRps: structure, motifs, and RNA synthesis machinery. Crit Rev Microbiol 43:753-778 